\title{
DNA Profiling in Relation to Missing Punjabi Persons in Iraq
}

\author{
Jatinder P Singh ${ }^{1}$, Ashok Chanana ${ }^{2}$, Jaspinder P Singh ${ }^{3}$
}

\begin{abstract}
In September 2017, a communication from the Ministry of External Affairs of India in connection with 39 Indian nationals held captive in Iraq was received. Out of 39 persons, 25 belonged to Punjab state of India. As per this communication, mass graves had been found in Mosul and Badish areas of Iraq. In order to establish the identity of mortal remains found in mass graves, blood samples of close blood relative of these missing persons were needed, which will enable the Iraqi authorities to match the deoxyribonucleic acid (DNA) samples with those found in mass graves. The Government of Iraq suspected these mass killings of Indians alleged to have been done by Islamic terrorists. The blood samples of the close relatives of 16 missing persons and blood samples of rest of persons were taken by experts of district headquarters of Punjab after guidance from this department. As per the requirements of the Iraq government, the blood samples of the close relatives of the deceased were taken on FTA cards that were sent through district administration of Amritsar to Ministry of External Affairs, Government of India, for onward transmission to Iraq embassy. Later on, the samples were sent to Iraq. After confirming their identity by the Iraq government, cadaveric remains of deceased in coffins were airlifted to India for their final rites. The collection of blood samples in these cases was done as per the standard guidelines issued by Centre for DNA Fingerprinting and Diagnostics (CDFD) Hyderabad on Flinders Technology Associates (FTA) cards. The role of this advanced technology proved to be a boon for the distressed relatives of the deceased by establishing the confirmed identity of deceased and providing solace.

Keywords: DNA, FTA cards, Iraq, Islamic terrorists, Mass graves.

AMEl's Current Trends in Diagnosis \& Treatment (2019): 10.5005/jp-journals-10055-0072
\end{abstract}

\section{INTRODUCTION}

A mass disaster is an unexpected event that causes serious injury and death to a number of people. Mass disaster events may be natural disasters (earthquakes, flooding, and tornadoes), accidental disasters (aircraft crashes, train crashes and derailments, and building fires), or intentioned terrorism acts (direct attacks on significant objectives and bombing of populated areas, including suicide attacks and deployments of chemical and biological weapons). Forensic identification of victims is essential not only for humanitarian reasons but also for civil or criminal investigative needs, and it is essentially based on forensic anthropology, fingerprints, forensic odontology, radiology, and deoxyribonucleic acid (DNA) typing. ${ }^{1}$

Experiences gained from previous mass fatality incidents reinforce the need to make all necessary steps to guarantee sample preservation for DNA analysis and to use suitable protocols for documenting the chain of custody of DNA sampling and body tracking.

The purpose of disaster victim identification may be to bring justice or closure to the families of the missing, and also to show respect to the victims themselves by treating them with individual dignity. ${ }^{2}$ It is questionable whether scientific or historic curiosity is an adequate substitute for these motives and such endeavors must be dealt with very carefully. There are some mandated rights and responsibilities in this area. For example, the Geneva Convention defines a responsibility of states to help in the location of graves of persons who have died while in their detention. ${ }^{3}$ The identification of human remains has been undertaken without the aid of DNA typing for many years, and a wide range of approaches are still appropriate for differing circumstances. ${ }^{4}$ However, in recent times, DNA technology has been extensively and usefully applied to the identification problem. ${ }^{5}$ The identification of the remains may only
${ }^{1-3}$ Department of Forensic Medicine and Toxicology, Government Medical College, Amritsar, Punjab, India

Corresponding Author: Ashok Chanana, Department of Forensic Medicine and Toxicology, Government Medical College, Amritsar, Punjab, India, Phone: +91 9915780056, e-mail: chananadoctor56@ gmail.com

How to cite this article: Singh JP, Chanana A, Singh JP. DNA Profiling in Relation to Missing Punjabi Persons in Iraq. AMEl's Curr Trends Diagn Treat 2019;3(2):93-95.

Source of support: Nil

Conflict of interest: None

be a part of the problem. It is important to remember that the position of the body or the burial may be a crime scene in itself and that much information may be obtained from a proper scene examination. ${ }^{6}$

\section{History}

On September 7, 2017, an official letter from Ministry of External Affairs was received by this department through district administration of Amritsar, Punjab, that Government of India has received a communication from the Government of Iraq regarding detection of mass graves in and around Mosul and Badish area. The detected mass graves were suspected to be 39 Indian nationals who were held captive in Iraq and out of these 39 persons 25 were citizens of India who belonged to Punjab state (Fig. 1). In order to establish the identity of mortal remains found in mass graves, blood samples of relatives of these missing persons were needed which will enable the Iraqi authorities to match DNA samples with those found in mass graves.

It was requested that two sets of blood samples of these close blood relatives (biological parents/brothers/sisters, etc.) of these

(c) The Author(s). 2019 Open Access This article is distributed under the terms of the Creative Commons Attribution 4.0 International License (https://creativecommons. org/licenses/by-nc/4.0/), which permits unrestricted use, distribution, and non-commercial reproduction in any medium, provided you give appropriate credit to the original author(s) and the source, provide a link to the Creative Commons license, and indicate if changes were made. The Creative Commons Public Domain Dedication waiver (http://creativecommons.org/publicdomain/zero/1.0/) applies to the data made available in this article, unless otherwise stated. 


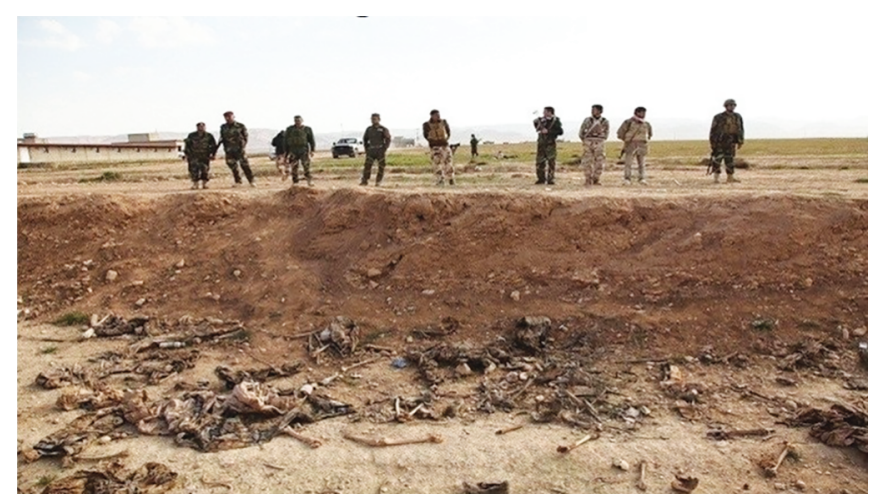

Fig. 1: A mass grave detected in Iraq

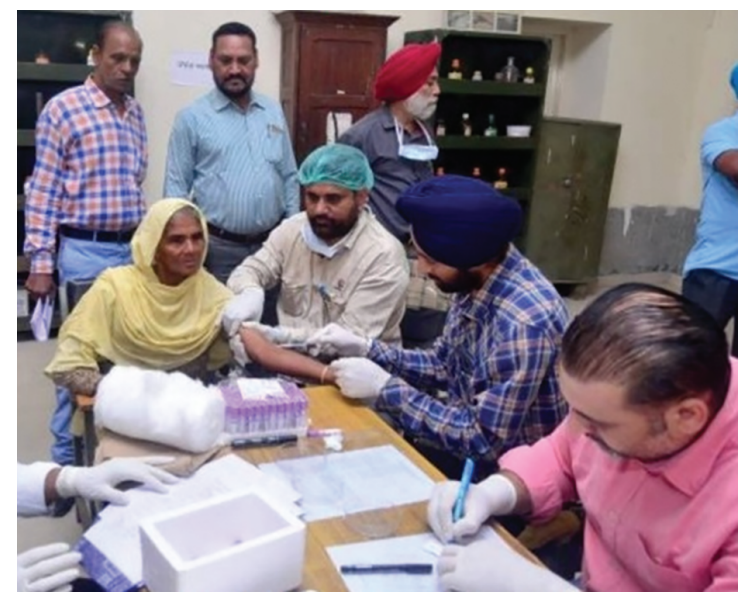

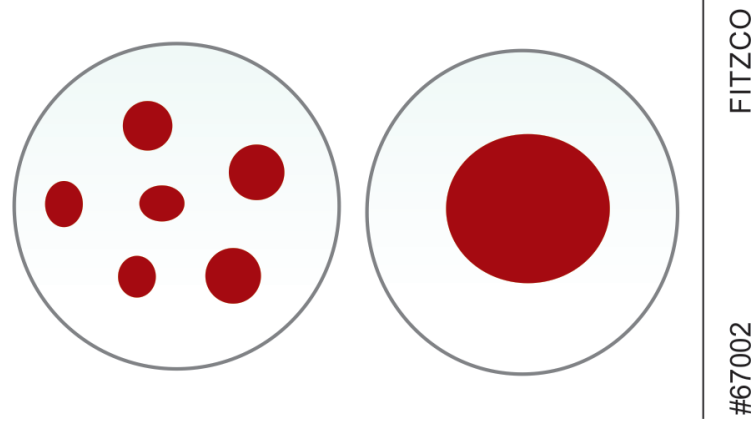

Fig. 2: FTA card with collected blood sample

missing persons from Punjab state as per appended list may be taken. The samples were to be accompanied with duly filled and prescribed forms as were received from the Government of Iraq for providing information in respect of missing persons. Blood samples were to be taken on FTA cards (Fig. 2).

All attributes, personal information, physical description, medical and dental information, and other necessary information pertaining to disappearance of persons, information about witness, and collector of DNA samples were to be supplied to Government of Iraq.

One set of sample should be analyzed by Punjab state government authorities for preparation of a DNA report for future reference and the other well-preserved blood sample in ready to dispatch condition will be forwarded to Iraqi authorities, following the protocol, governing dispatch of such biological samples.

Fig. 3: Collection of blood samples

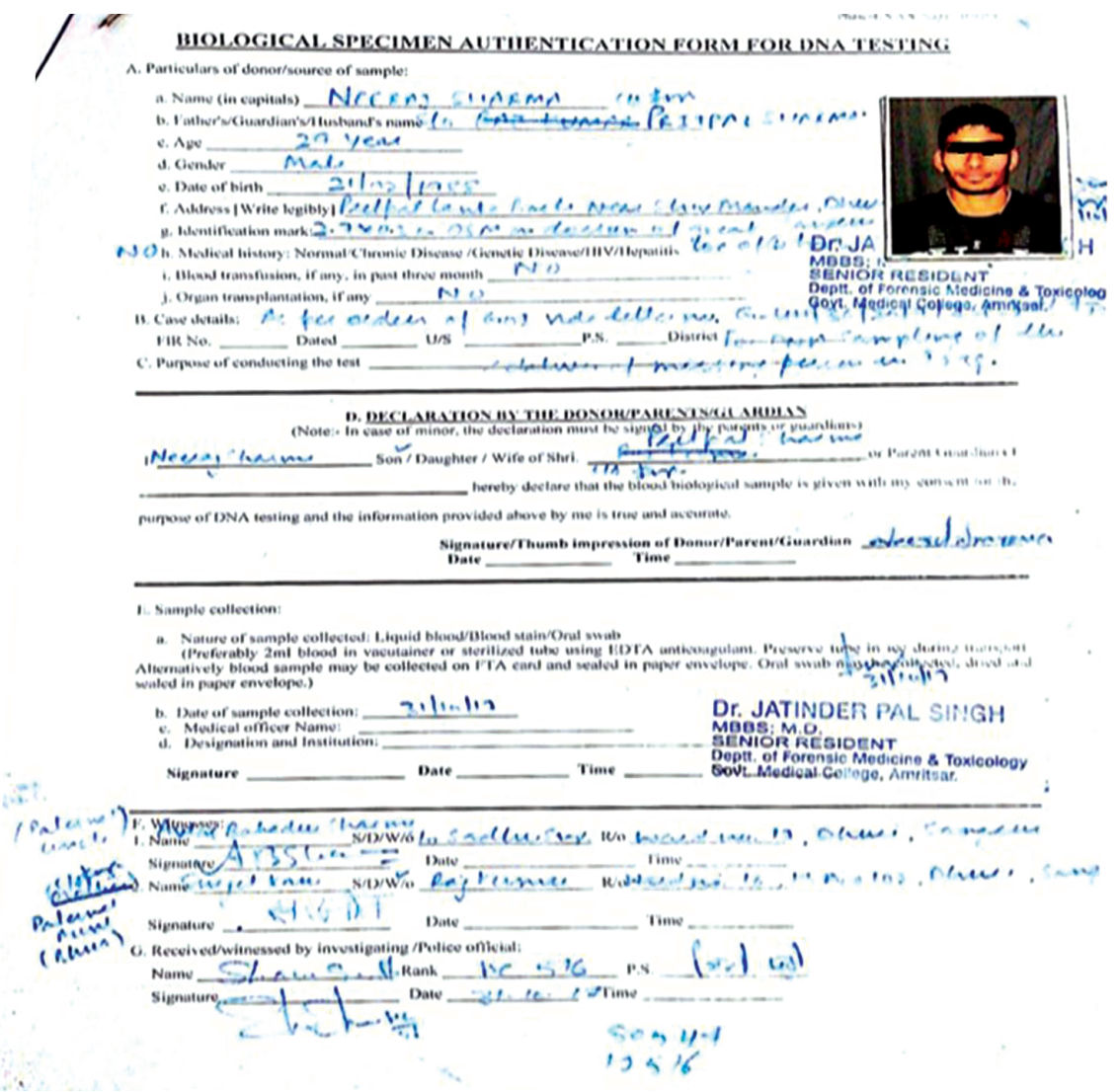

Fig. 4: Biological specimen authentication performa 


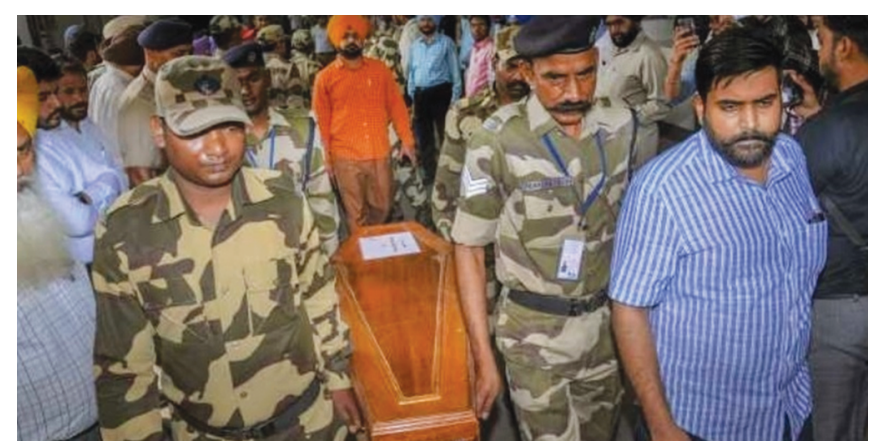

Fig. 5: Mortal remains were airlifted from Iraq to India

\section{Materials and methods}

As per the Government of Iraq, the blood samples were to be collected on FTA cards but this department was not having these cards. So it caused delay in the collection of blood samples, thereby causing apprehension in the minds of the relatives of missing persons and this point was highlighted in the electronic and print media also.

Keeping in view the sensitivity and urgency of the issue, director, Centre for DNA Fingerprinting and Diagnostics (CDFD) Hyderabad, was contacted and whole issue was discussed with him and he agreed to supply the DNA kits. A laboratory technician of the department with an authority letter and official letter was flown to Hyderabad for collecting DNA kits from director, CDFD. In every case, blood samples of three close relatives were taken (Fig. 3) and as per the procedure that is after filling the performa pertaining to physical attributes of missing persons, biological specimen authentication performa (Fig. 4), photographs, and signatures of the doctor collecting samples and the witness were sent to the Ministry of External Affairs of India for onward transmission to Embassy of Iraq, New Delhi.

\section{Conclusion}

The blood samples of all the relatives of missing persons of Punjab were matched with the cadaveric remains found in graveyards in Mosul and Badish areas of Iraq. So, all the missing persons thereby were identified and the statement in this regard was given by the late honorable minister of external affairs in the Parliament.

Later on, cadaveric remains of these missing person were airlifted to India for their final rites by Government of India (Fig. 5). Though the analysis of biological sample is done in the laboratory but the selection, collection, preservation, and dispatching of the biological samples fall within the domain of the medical personal. By adopting the accurate procedure, the accurate result was revealed, thus leading to establishment of identity of individuals.

\section{References}

1. Mass Fatality Incidents: A Guide for Human Forensic Identification. NCJ 199758, June 2005, Special Report by National Institute of Justice. Available from http://www.ncjrs.org/pdffiles1/nij/199758.pdf. Accessed: April 30, 2005.

2. Williams ED, Crews JD. From dust to dust: ethical and practical issues involved in the location, exhumation, and identification of bodies from mass graves. Croat Med J 2003;44(3):251-258.

3. Ferllini R. The development of human rights investigations since 1945. Sci Justice 2003;43(4):219-224. DOI: 10.1016/S1355-0306(03)71780-8.

4. Cox M. A multidisciplinary approach to the investigation of crimes against humanity, war crimes and genocide: the Inforce Foundation. Sci Justice 2003;43(4):225-227. DOI: 10.1016/S1355-0306(03)71781-X.

5. Ganswindt $M$, Ehrlich E, Klostermann P, et al. Bone finds: a challenge to forensic science. Leg Med 2003;5:382-385. DOI: 10.1016/s13446223(02)00137-2.

6. Skinner M, Alempijevic D, Djuric-Srejic M, et al. Guidelines for international bio-archaeology monitors of mass grave exhumations. Forensic Sci Int 2003;134(2-3):81-92. DOI: 10.1016/s0379-0738(03)00124-5. 